\title{
Battle to save education enters critical phase in north Germany
}

\section{Düsseldorf}

THE battle to maintain a vital educational system in the face of acute economic pressure is being waged with particular vigour in the northern German Land of North Rhine-Westphalia (NRW). The government is moving into the critical phase of a 15-year plan - the 'university structure plan 2001' - to reorientate its universities toward high technology.

Elections approaching in 1990 on both state and federal levels have spurred North Rhine-Westphalia's Social Democratic (SPD) government to put its programme in place by next year. The task seems next to impossible: high unemployment, huge budget deficits, the expense of new equipment and the political resistance to eliminating courses of study pose enormous problems.

Northern West Germany and NRW in particular have suffered under the rationalization of the steel and coal industries, and new technology-oriented companies have primarily settled in southern West Germany in the years of rebuilding following the Second World War.

Science Minister Anke Brunn (SPD) has dealt with the problem pragmatically since inheriting her post in 1985. The overall strategy since the early 1980s has been to cut unnecessary courses in teaching or humanities, where students would not find jobs anyway; to create regional centres in both natural sciences and humanities and reduce duplication in neighbouring universities; and to increase numbers of graduates in fields where there are expected to be plenty of jobs, such as electronics or information sciences.

To the great relief of the universities, which are suffering from student overpopulation as a result of the post-war baby boom, Brunn has warded off the Finance Minister's budget axe and ensured that personnel will not be cut until at least 1990. Aware of the risk that frustrated students might go to universities in southern Germany (which is enjoying something of an economic boom), Brunn is attempting to make NRW's universities as attractive as possible through a publicity campaign.

Last month, university administrators were bowled over when they found out that their budgets for small- and mediumsized equipment would be increased dramatically after a freeze that had lasted several years. NRW had to go further into debt to finance the equipment renewal programme, another sign that it considers research a "new raw material" for the future, as NRW Minister-President Johannes Rau (SPD) recently announced.
But the reorganization plans have met with resistance from university rectors who feel that they are losing their autonomy to the Science Ministry. Although they agree that reorientation is necessary, the rectors reject the Ministry's heavy-handed, insensitive approach. Rector Klaus Habetha of the Technische Hochschule at Aachen regrets that Brunn has not called for expert advice from the universities themselves in deciding where to make the next round of cuts, which will involve a broad range of fields especially

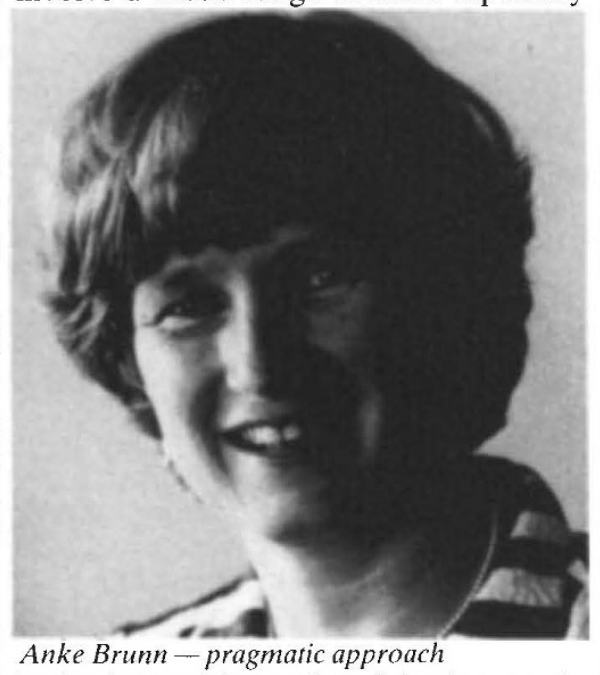
in the humanities and social sciences. In future, he said he hopes that cuts will not just be "decreed from the top" but rather that "a common solution" can be achieved.

Rector Knut Ipsen of the University of Bochum complained that a small university such as Bochum, which offers a lot of small "exotic" subjects in humanities and the arts, suffers disproportionately under across-the-board cuts. For example, under the Ministry's plans, the department of modern Greek in Bochum would be reduced to one half position. He considers such cuts "an absurdity".

Brunn put the situation in a much more positive light. In the natural sciences and engineering, NRW has "no problems" attracting and holding onto good researchers. The expansion of the 1970 s created high standards that have been maintained, she said. The situation could be improved still further, she says, by a fairer distribution of federal research funds. In the ongoing struggle between the federal and Länder governments for funds Brunn feels that NRW has been shortchanged. She attributes this to regional bias on the part of referees.

Though the situation is improving as more NRW researchers sit on grant committees, Brunn still feels that NRW is discriminated against by the Max Planck
Sagdeev to leave Moscow post London

Academician Roald Sagdeev, director of the Space Research Institute in Moscow, is planning to step down from his post in October, after an election for a successor conducted in the true spirit of perestroika.

This development is important both because it is meant, in part, as an example to others within the Soviet Academy of Sciences system and because Sagdeev has been influential in fostering relations between Soviet science and the rest of the scientific community during the past four years. Sagdeev said this week that he plans to become a working scientist after having been at the Space Research Institute for fifteen years.

Under the rules governing the appointment of the directors of academy institutes, institutes can only recommend the successor of a retiring director to the praesidium of the academy, which retains the power of preferment. But in the circumstances (and the present climate) it is hard to think that the recommendation would be declined.

Sagdeev's intended departure will nevertheless be a disappointment for many scientists in the West who have benefitted from his enthusiasm for carrying their instruments on Soviet spacecraft.

Among Soviet research establishments, the Space Research Institute in Moscow stands out for its efficiency and effectiveness. Sagdeev himself has been personally responsible for much of the scientific success of the Soviet space programme in the past decade and more.

Even by present standards, Sagdeev is something of a radical. He was elected a delegate to last month's special conference of the Soviet Communist Party, at which he proposed the amendment to the official roster of resolutions requiring that the ten-year retirement rule should apply even to the general-secretary of the party (sitting over his left shoulder), with whom he is well-connected.

The chances are that Sagdeev's intention to step down from a post he has made influential will not inhibit his frequent appearances in the West or even diminish his personal influence on the course of East-West events. Latterly, he has been contributing regularly to the glasnost newspaper Moscow News, which may be a sign of what lies ahead. John Maddox

Society. In the humanities and social sciences, the crisis mentality pervading the universities cannot be attributed to the Ministry, said Brunn. According to her statistics, there will be over 2 million academics in West Germany by 2000 but only 800,000 positions.

Steven Dickman 